\title{
Technological and economic factors of increase of domestic production of ornamental crops
}

V. Yezhov,

Academician of the NAAS, Doctor of Technical Sciences

O. Pishchenko,

Ph.D. in Agricultural Sciences

O. Litovchenko

Institute of Horticulture of NAAS, Pryluky experimental station by IH NAAS

The purpose. To evaluate perspectives of growth of production of ornamental crops on the basis of technological and economic premises. Methods. Creation and analysis of database on economy of production and the prices of the market, competitive strength of products. Field and laboratory methods of selection of ornamental plants. Results. Use of up to date technologies of production alongside with sharp rise in prices of import has ensured the low or equal price of domestic production and its competitive strength. Conclusions. Use of modern techniques and positive market condition cause economic expediency of own production of the majority of ornamental crops, and open opportunities for their export.

Key words: ornamental crops, techniques, cost price, prices, export.

Formulation of the problem. In the domestic production of ornamental crops over the past 30 years there have been radical changes due to the appropriate transformation of forms of subordination, ownership, organization of the process and its technological support. As a result, at the beginning of this century, in our country, essentially new production was formed, which, unlike the previous subjects of communal property, relied mainly on private capital and foreign technology. However, the initial tangible development of this segment of the agrarian complex was seriously affected by the economic crises of 2008-2009 and 2014-2015, while the analysis of the latter showed that along with its negative consequences there is also a certain positive effect due to the sharp fall in imports of ornamental plants with possible increase of domestic production (1). Nevertheless, for the final determination of the prospects for the development of crop production of ornamental plants, an analysis of its modern technological and economic components remains necessary, which was the purpose of the presented study.

Analysis of recent research and publications. A brief review of existing information on ornamental plants suggests that in the technological aspect, their production has changed radically over the past years. Most ornamental trees and shrubs are now grown instead of open soil in containers, giving some technological and economic advantages (2) and allow 7-8 years to create powerful production at relatively low levels with millions of profits. Old, unprofitable greenhouse complexes replace smaller areas (up to $500 \mathrm{~m}^{2}$ ), but economical in heating, with temperature, humidity control, active use of cassettes and containers (3). To increase the efficiency of plant propagation, growth regulators $(4,5)$ and plant rooting (6) are actively used, superabsorbents - extenders of optimum substrate moisture $(7,8)$; micropropagation is increasingly practiced $(9,10)$. The complex use of these techniques is reflected in the economic component - for example, the use of cassettes and containers for the cultivation of seedlings of juniper with subsequent cultivation in open soil reduces the cost of finished products by $13 \%(11)$, and the use of micropropagation for the production of hawthorn plants with subsequent cultivation - by $15 \%$ (12). But the final cost of decorative plants eventually regulates the market with its main factors "supply and demand"; for example, in Moscow and the region in 2013, prices for herbaceous perennial crops ranged from 1.5 to 
$13 €$, coniferous shrubs - 8-120€, leafy trees - 150-450€, and large-sized - 500-2500€ (13). This indicates a speculative approach to price formation against the backdrop of financial capacity and lack of awareness of buyers. In our country, analytical data on prices on the market of ornamental plants are extremely limited.

Materials and methods. The paper analyzes the database of information on the wholesale prices for 2016-2017 of the most important nurseries in Ukraine for ornamental plants. Some results of breeding and technological researches of 2014-2017 in the collection fund of ornamental plants of the Pryluky experimental station are also included in the analysis. For conducting individual experiments in the technological and breeding directions, common methods of field and laboratory experiments are used.

Results. It was calculated the actual cost of growing roses on a cut in the greenhouses (Table 1). It is about $14 \mathrm{UAH}$. for a one flower and in its structure more than $68 \%$ is for heating, which fully confirms the necessity of taking organizational measures for its economy. At the same time, pay is relatively modest compared to Western European nurseries.

Table 1. Structure of the cost of growing roses per cut

\begin{tabular}{|l|l|c|}
\hline Cost component & $\begin{array}{l}\text { Cost of 1000 } \\
\text { pieces, UAH from sum }\end{array}$ & \\
\hline Pay & 2451,0 & 16,8 \\
\hline Payroll tax & 850,0 & 6,3 \\
\hline Auxiliary materials & 210,0 & 1,4 \\
\hline Heating & 9800,0 & 68,5 \\
\hline Production cost & 500,0 & 3,5 \\
\hline Other cost & 500,0 & 3,5 \\
\hline Sum & 14311,0 & 100,0 \\
\hline
\end{tabular}

As the analysis of literature has shown, the cost of ornamental plants is significantly influenced, apart from the above, other factors, among them the technologies used and indirectly - selection works related to the decorative of plants as an element of their market value. To estimate these factors in the plant's collection of Pryluky station, which contain varieties - roses (225), irises (220), day lilies (119), rhododendrons (50), cannas (40), hosts (31), clematis and lilacs (by 20 ) works are under way to create new varieties adapted to the conditions of the Left Bank of Dnepr and competitive best ones on the basis of decorative features. As a result of this work, over the past 4 years, 2 types of day lilies, by 1 - cannas and iris have been created, hybrid forms of other flowers are present at different stages in the variety study. At the same time, experiments are conducted to optimize breeding modes for promising species and plant varieties, using growth and rooting stimulants. In particular, for western red cedar and juniper , the efficiency of using for the propagation of wood-fibered cuttings has been proved, with the percentage of rooting being 82 and $84 \%$, respectively, for the use of stimulants of 'Fumar' and 'Amber Acid'. 100\% rooting has been achieved for some deciduous species of rhododendron - Rhododendron Knapp Hill hybrid 'Fabiola', 'Golden Sunset', Rhododendron yedonense, R.obtusum 'Red', 'Geisha purple', evergreen variety R. hybrid 'Cardine'; $67 \%$ - R. caucascum 'Cunningham's white'. For other types of rhododendron with a percentage rooting up to $20 \%$ work on optimizing the process is ongoing.

Domestic varieties of ornamental flowering plants still occupy a small niche in the ukrainian market of sale, dominated by foreign varieties and technologies with the above elements. The highest prices on it naturally belong to ornamental wood crops (Table 2). 
Table2. Prices of Ukrainian nurseries on decorative trees, UAH.

\begin{tabular}{|l|lc|l|}
\hline Cultivares & $\begin{array}{l}\text { Growing in open ground } \\
\mathbf{3} \text { years } \quad \text { more 5 years }\end{array}$ & $\begin{array}{l}\text { Containers } \\
\mathbf{3} \mathbf{~}\end{array}$ \\
\hline Common birch & $245-270 \quad$ from 1800 & 325 \\
\hline Maple & $155-300 \quad$ from 600 & $155-410$ \\
\hline Common catalpa & $350-715 \quad$ from 3000 & $130-190$ \\
\hline Pine trees & $150-450 \quad$ from 1090 & $95-185$ \\
\hline Spruce & $140-410 \quad$ from 1720 & $60-160$ \\
\hline Western red cedar & $180-270 \quad$ from 600 & $48-153$ \\
\hline
\end{tabular}

With the exception of the catalpa, the price of which most likely reflects the increased demand, prices for the main types of decorative trees are quite close, especially in containers. It should be noted that in foreign nurseries, prices for similar products in open soil are much higher; at the course of the dollar it is $4900-11500 \mathrm{UAH}$. At the same time, foreign products in containers close to the domestic one - $200-490$ $\mathrm{UAH}$, which indicates the high cost of cultivating ground.

Table 3. Prices of Ukrainian nurseries on decorative shrubs, UAH.

\begin{tabular}{|l|c|c|}
\hline Cultivares & Open ground & Containers 3 L \\
\hline Spindle tree fortunii & $39-70$ & $270-450$ \\
\hline Lilac & $24-113$ & $69-127$ \\
\hline Box tree & $45-140$ & $99-160$ \\
\hline Juniper & $185-490$ & $60-189$ \\
\hline
\end{tabular}

A similar tendency is also characteristic for decorative shrubs. Except for juniper, diversity and increased demand for which made a wide range of prices, the price of other open-air crops is close; the same is typical for containers product without spindle tree. Similar container products of foreign nurseries at the course of the dollar to the UAH 26.0 are sold at 350-400 UAH, except for lilacs, the low demand for which was reflected in the price - about $80 \mathrm{UAH}$. Thus, the current prices of Ukrainian nurseries in the tree and bush decorative cultures determine their dominance on the market. A similar pattern has developed on perennial grass crops and lawn grasses; The price of the last from domestic manufacturers is 50-95 UAH for $1 \mathrm{~kg}$, which is twice lower than the imported analogues. The price of perennials in the open ground is 12-14 UAH per unit, while of popular hosts - UAH 32; at the same time, the same products in containers are much more expensive - 39-72 UAH, which is possible compensated by its high quality. Quite interesting situation has developed on the prices for the cut of flowers (tabl.4).

Table 4. Prices for cut flowers

\begin{tabular}{|l|c|c|}
\hline Cultivares & $\begin{array}{c}\text { Domestic } \\
\text { nurseries }\end{array}$ & $\begin{array}{c}\text { Import and } \\
\text { wholesale sale }\end{array}$ \\
\hline Rose & $6,0-18,0$ & $12,3-28,0$ \\
\hline Tulip & $6,5-14,0$ & 12,0 \\
\hline Carnation & 5,0 & 5,0 \\
\hline Chrysanthemum & $3,0-16,5^{*}$ & $2,0-5,0$ \\
\hline
\end{tabular}

Prices of domestic enterpises on most the popular among the sections of the rose in most have become lower than the *branch with several flowers import, which determines the high competitiveness of this product in the market. In fact, the same pattern is traced through the tulips, while the prices of the carnation are equal, and the import chrysanthemum is still more attractive at the price.

Unlike cut flowers, bulbs of ornamental plants (tulips, narcissus, hyacinths, etc.) remain in our market exclusively imported, mainly from the Netherlands. Proposals of domestic firms for their resale in the 
spring of 2017 were (for 1 pc.) - tulip 6.6-19, dahlias 12-20, asian lily - 8-14, hyacinth 12-39, narcissus 5,3-9,3 UAH.

As a whole, the overall balance of retail flower decorative products in Ukraine in 2016 amounted to 51: $49 \%$ in favor of domestic products, with a total volume of sales of more than 530 millions UAH. An important feature of this result is that almost a third of sales of ornamental plant products fell to Kyiv and Kyiv region, indicating a higher purchasing power of the population of this region. As for other regions, about $6 \%-8 \%$ of the total sales of goods is accounted for by 5 regions - Dnipropetrovsk, Kharkiv, Lviv, Odessa and Donetsk, in general in these regions one third of the total. Finally, the last third of flower decorative products are sold in other regions of the Ukraine, where there is a potential for growth in sales with rising incomes.

It can be noted that the existing technological possibilities and economic basis of domestic crop cultivation of decorative crops have developed today so that it gradually becomes competitive in relation to similar imported products and slowly displaces it from the domestic market. Confirmation of this tendency is another indicator - the export of ornamental plants from Ukraine to other countries (Table 5). It should be noted that from 2014, the export of this product from our country did not occur at all. Another interesting fact is that besides the former traditional partners of Ukraine in this segment of economic activity - the Russian Federation, Belarus, Moldova, on the first time domestic decorative plants were exported to Poland and even to the Netherlands. Of course, this was mainly due to the selling prices of products - according to calculations, the average price of cut of roses to Belarus was $0.48 €$, to Poland $0.4 €$, whereas to the Netherlands - only $0.29 €$. But this prices are apparently satisfied by domestic producers, if we take into account the above data on prices for this product in the domestic market and the actual absence of value added tax in the case of exports. In total, in 2016, ornamental crops were exported in the amount of about $\$ 3$ million; compared with imports, this indicator is negative, but the very fact of the export recovery and its geography is the main thing.

Table 5. Export of ornamental plants from Ukraine in 2016

\begin{tabular}{|l|l|c|}
\hline Group of plants & Country an importer & $\begin{array}{c}\text { Cost of } \\
\text { goods, } \\
\text { thous.\$ }\end{array}$ \\
\hline Rose bushes & Poland Other & 23,0 \\
on EU & 3,5 \\
\hline Other bushes and trees & Moldova & 807,3 \\
& Russia & 459,6 \\
& Belarus & 281,1 \\
& Poland & 270,7 \\
\hline Cut roses & Belarus & 407,4 \\
& Poland & 585,4 \\
& Netherland & 168,8 \\
\hline
\end{tabular}

Summarizing the above, it is worth recalling the conclusion from our previous publication about the positive impact of the economic crisis of 2014-2015 on the revival of domestic crop production of ornamental crops. According to the above materials, most domestic nurseries, which from the beginning of the 2000s actively absorbed the foreign experience of producing decorative crops, were prepared for this situation in the technological and organizational terms, as a result of which last year there was a noticeable replacement of the imported products by own. The above economic analysis shows that today domestic products at its cost are largely competitive with regard to imports, as evidenced in particular by its export figures. As for domestic science, it actively works both on the technological aspects of the reproduction of ornamental plants, and in the selection of breeding works for the creation of varieties 
adapted to local conditions and competitive to the best foreign analogues in terms of decorative features; there is a hope that the domestic production of ornamental crops will continue to have a decent scientific support.

\section{Conclusions.}

Use of modern techniques and positive market condition cause economic expediency of own production of the majority of ornamental crops, and open opportunities for their export.

\section{Literature.}

1.Yezhov V.M., Lytovchenko O.P. Rynok dekoratyvnykh roslyn Ukrayiny $v$ umovakh suchasnoyi ekonomichnoyi kryzy. - Visnyk ahrarnoyi nauky. - 2016. - 20-24.

2.Razumovskyy V.N. Effektyvnost' vyrashchyvanyya sazhentsev $v$ dekoratyvnykh pytomnykakh. Lektsyya v Tymyryazevskoy SKhA. - 2011. - first.line.com.ua/portal/mr/fabrika dekorativnyh rastenij.

3.Aukhadeev M.H. Povyshenye effektyvnosty vyrashchyvanyya tsvetov y odnoletnykh kul'tur $v$ uslovyyakh zakrytoho hrunta.// avtoref.dys. doktora ekonom.nauk. - Saratov : Saratovskyy HU. - 2003. $32 \mathrm{~s}$.

4.Hrechanyk R.M.Vplyv rehulyatoriv rostu na skhozhist' nasinnya sosny zvychaynoyi / R.M.Hrechanyk, L.O.Hula, V.Yu. Tbur. - Visnyk NLTU. - 2014. - 24(9). - 41-45.

5.Al.Malki A.A., Elneer K.M.S. Influence of auxin and cytokinine on in vitro multiplication of Ficus Anastasia. - African J. Biotechnology. - 2010. - 9(5). - 635-639.

6.Lisovyy M.M. Osoblyvosti vidtvorennya henotypiv dekoratyvnykh form buku lisovoho // avtoref. dys.. kand.. s.-h. nauk. - L'viv : NLTU. - 2010. - 16 s.

7. Tyshchenko K.Yu., Sheveleva Yu.A. Stymulyatory rosta rasteniy oksanovoho ryada // 2-ya mezhd. Stud. Konf., Novosybyrsk, 2015. - MNSKh - 2015 : Sel'skoe khozyaystvo. - s.43.

8. Fuchylo Ya.D. Vplyv superabsorbentiv na ukorinennya zhyvtsiv i rist zhyvtsevykh sadzhantsiv chornykh topol'. / Ya.D.Fuchylo, M.V.Sbytka, V.M.Litvin, O.Ya.Fuchylo. - Lisnytstvo i ahromelioratsiya. Kharkiv : Ukr NDILHA. - 2009. - 116. - 153-157.

9. Kushnir H.P., Sarnyts'ka V.V. Mikroklonal'ne rozmnozhennya roslyn. Teoriya i praktyka. - Kyyiv : Naukova dumka. - 2005. -272 s.

10.Tomaszewska - Sowa M., Figas A. Environmental and ecological aspects of cultivation of selected energy and herbal plants propagated by in vitro culture. - Infrastruktura i ekologia terenow wiejskich. 2014.- 4(3). - 1457-1465.

11. Provorchenko A.V. Effektyvnost' proyzvodstva materyalov mozhzhevel'nyka $v$ zavysymosty ot vyda yskhodnoho materyala / A.V.Provorchenko, S.A.Byryukov, Yu.V.Sedyna, O.A.Provorchenko. Nauchniy zhurnal Kubanskoho HAU. - 2013. - 93(9). - 91-94.

12. Nebykov M.V., Tsyhanenko L.V. Ekonomichna efektyvnist' vyroshchuvannya sadyvnoho materialu predstavnykiv rodu Crataegus L. z vykorystannyam biotekhnolohichnoyi lanky. - Avtokhtonni ta introdukovani roslyny. - 2013. - 105- 107.

13.Ketner Y.A. Struktura y znachenye rossyyskoho rynka dekoratyvnykh rastenyy $v$ assortymentnom razreze pytomnykov. - Vektor nauky THU. Seryya : ekonomyka y upravlenye. - 2013. - 1(12). -66-69. 